\title{
多結晶モデルによる形状記憶合金の機械的性質の解析
}

\author{
小野 陽 ${ }^{*}$ 佐藤 敦** 太田裕之愺
}

J.Japan Inst.Metals,Vol.50,No.12(1986),pp.1049-1055

An Analysis of the Mechanical Properties of Shape Memory

Alloys Based on a Polycrystal Model

\begin{abstract}
Noboru Ono*, Atsushi Satoh** and Hiroyuki Ohta***
The scheme recently proposed by the authours on the basis of the Taylor model to deal with the deformation of polycrystals caused by the stress induced martensitic transformation(SIM) has been further extended to describe the recovery stress associated with the reverse transformation upon unloading. According to this scheme, the "modified" Taylor factor, $M^{\prime}$ has been calculated as a function of grain orientation for the cases of tension and compression deformation in the shape memory alloys such as CuZnAl, CuAlNi and TiNi. The results demonstrated the difference in the plastic anisotropy for SIM of grains under the polycrystalline constraint from that of isolated crystalites. The strain hardening due to the internal stresses caused by the grain orientation dependence of volume change has been shown to be insignificant in these alloys. General discussion has been given to the yield stress, recovery stress, pseudoelastic hysteresis, recovery strain, ductility, and strain hardening of the shape memory alloys, in relation to the magnitude and orientation dependence of $M^{\prime}$.
\end{abstract}

(Received August 23, 1986)

Keywords : stress induced martensitic transformation, pseudoelasticity, polycrystal plasticity, the Taylor model, shape memory alloys, plastic anisotropy

I. は じめに

形状記憶合金の工学的応用の広がりが期待されている が，それらが工業材料として利用されるときには汪とんど の場合,多結晶状態で用いられる。多結晶形状記憶合金の性 質を理解するにはマルテンサイト変態の結晶学や変態, 変 形に対する結晶粒界の役割などについての微視的な研究に 加えて結晶粒間の相互拘束の效果を評価することが必要と 考えられる。そこで著者らは前報(1)(以下Iと引用する)に 沶いて，多結晶合金の応力誘起マルテンサイト変態 (SIM) による一軸変形を Taylor モデルによって解析する方法を 考察した。それによれば，マルテンサイト変態に伴う体積 変化のために多結晶の SIM そ执いては Taylor モデルに 打ける均一ひずみの仮定が満たされない，そこで偏差応 力,偏差ひずみだけを Taylor モデルで取扱い，その後に必 要なら静水圧応力と体積変化の影響を評価, 補正する方法 を提案した。これによって応力とひずみの偏差成分に対し て定義された，言わば「修正された」Taylor 因子 $M^{\prime}$ が 求められ，それ静水圧応力と体積変化の寄与を考慮して 平均した值 $\bar{M}$ にって多結晶の降伏応力が予測できる.
また， $M^{\prime}$ の結晶粒方位依存性，すなわち SIM による変 形の塑性異方性から多結晶形状記憶合金の変形挙動汇対す るさまざまな知見が得られると期待される。

本研究ではまず】の考察を拡張して SIM の時と同じ $\bar{M}$ をマルテンサイトから母相への回復応力に対しても用いる ことができることを示す．次に，いくつかの合金の一軸変 形に対してこの方法を適用して上記の修正 Taylor 因子 $M^{\prime}$ を計算した結果を報告する。取り上げたのは $\mathrm{CuZnAl}$ 合金の $\beta_{1}^{\prime}, C u A 1 N i$ 合金の $\gamma_{1}^{\prime}$ と $\beta_{1}^{\prime}$, それに TiNi 合金の 防の各マルテンサイトーの変態である。それに基づいて 多結晶の降伏応力, 回復応力, 擬弾性ヒステリシス, 体積 変化とその不均一の影響，塑性異方性の Schmid 因子によ る評価との違い，その異方性と合金の延性との関連，応 カーひずみ曲線の形状などについて検討する。

\section{II. 回復応力}

以下において $I$ の各式を例えば式 $(I-1)$ と引用する。ま た記号の定義もエにしたがうものとする.

ある応力 $\sigma_{\mathrm{i}}^{\mathrm{R}}$ のるとですでに存在するマルテンサイトバリ

* 東北大学工学部 (Faculty of Engineering, Tohoku University, Sendai)

**東北大学大学院生, 現在 :ソニーマグネプロダクッ(株) (Graduate Student, Tohoku University, Sendai. Present address : Sony Magnetic-products Inc., Tagajoh)

**** 東北大学大学院生 (Graduate Student, Tohoku University, Sendai) 
アント $s$ が不安定となって収縮する条件は式（Ｉ－15）にお いて $W$ と $\Delta F_{\text {chem }}$ の符号を反転したものとなって，

$$
\begin{aligned}
& W=\sigma_{\mathrm{i}}^{\mathrm{R}} e_{\mathbf{i}}^{\mathbf{s}}=W^{* \mathbf{R}} \\
& W^{* \mathbf{R}}=-\Delta G_{\mathrm{f}}-\Delta F_{\mathrm{chem}}=W^{*}-2 \Delta G_{\mathrm{f}}
\end{aligned}
$$

と書ける。、ルテンサイトの成長の時と異なっている点は 存在するバリアントが定まっていることである。すなわち それらが SIM によって作られたものであれば，Iの考察 が示すようにそれらは式(I-15)，改めて書けば

$$
\sigma_{\mathrm{i}} e_{\mathrm{i}}^{\mathbf{s}}=W^{*}
$$

を満足している．そのようなバリアントが Taylor 拘束を 満たしながら同時に収縮しなければならないので，除荷に よって回復ひずみの生じる条件は，式 (3)を満足するすべ てのバリアントについて式 (1) が満足されることである. 式 (1) と式 (3)は右辺の大きさが違うだけであり，W*R， W*はバリアントによらない值と考えているので，ひずみ の回復が起こる応力 $\sigma_{\mathrm{i}}^{\mathrm{R}}$ は明らかに次式を満足する.

$$
\sigma_{\mathrm{i}}^{\mathrm{R}}=\sigma_{\mathrm{i}} W^{* \mathrm{R}} / W^{*}
$$

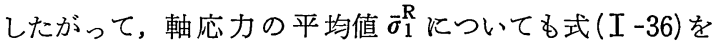
参照して

$$
\bar{\sigma}_{1}^{\mathrm{R}}=\bar{\sigma}_{1} W * \mathrm{R} / W^{*}=\bar{M} \cdot W * \mathrm{R} / \eta
$$

が成立する。 $W^{* \mathrm{R}}$ はバリアントの収縮に対する抵抗を示 す特性值であって式 (2)のようにバリアントの成長に対す

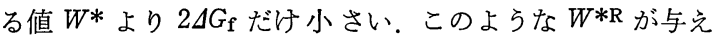
られれば, SIM により変形した多結晶の逆変態応力は, 前 方への変形と同じ幾何学的因子 $\bar{M}$ を用いて式 (5)のよう に与えられる。 また, 擬弾性ループの応力ヒステリシス $\Delta \bar{\sigma}$ は

$$
\begin{aligned}
\Delta \bar{\sigma} & =\bar{\sigma}_{1}-\bar{\sigma}_{1}^{\mathrm{R}} \\
& =2 \bar{M} \Delta G_{\mathrm{f}} / \eta
\end{aligned}
$$

と与えられる。

\section{III. 修正 Taylor 因子 $M^{\prime}$ の計算方法}

Iで求めた偏差応力 $\sigma_{\mathbf{i}}^{\prime}$, 偏差ひずみ $\varepsilon_{\mathbf{i}}^{\prime}$ に関する単結晶 の降伏条件式（I - 22)を改めて書けば次のようである.

$$
\begin{aligned}
& \text { i) } \sigma_{\mathbf{i}}^{\prime} m_{\mathbf{i}}^{\mathbf{s}}=W^{\prime}\left(T, \sigma_{\mathrm{m}}\right) / \eta \\
& \text { であれば } \\
& v^{\mathrm{s}} \geqq 0
\end{aligned}
$$

Iでの仮定にしたがって偏差ひずみ Taylor 拘束が加わるとすると各結晶粒の $\varepsilon_{\mathrm{i}}^{\prime}$ は多結晶全体
の平均の偏差ひずみ $\bar{\varepsilon}_{\mathbf{i}}^{\prime}$ に等しい.

$$
\varepsilon_{\mathbf{i}}^{\prime}=\bar{\varepsilon}_{\mathbf{i}}^{\prime}
$$

一軸変形を考えているので, 試料軸に沿う座標系では $\bar{\varepsilon}_{\mathbf{i}}^{\prime}$ は

$$
\left\{\bar{\varepsilon}_{\mathbf{i}}^{\prime}\right\}=\bar{\varepsilon}_{1}^{\prime}\{1,-1 / 2,-1 / 2,0,0,0\}
$$

と書ける。この $\bar{\varepsilon}_{\mathbf{i}}^{\prime}$ に対して式 (1)，式 (2)を同時に満足 する応力, すなわち降伏曲面の角点の応力 $\sigma_{\mathrm{i}}^{\prime} \mathrm{c}$ はすべり変 形の場合と同様に Bishop と Hill の最大仕事の原理 ${ }^{(2)}$ を用 いて求められる。すなわら解くべき問題は,

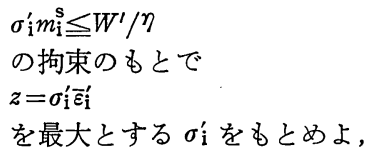

という線形計画法の問題となる。これを改訂シンプレック ス法 ${ }^{(3)}$ を用いて解いた。 得られた解, $\sigma_{\mathbf{i}}^{\prime} \mathrm{c}$ から求める $M^{\prime}$ は式（I -28)のように定義される。改めて書けば,

$$
M^{\prime}=\frac{3}{2} \eta_{\sigma_{1}^{\prime}} / W^{\prime}=\eta_{v} / \bar{\varepsilon}_{1}^{\prime}
$$

このような計算を $[001]-[011]-[111]$ 基本ステレオ三角 形内にほぼ均一に選んだ 861 の各方位について繰返して $M^{\prime}$ の粒方位依存性を調べた。また均一な粒方位分布を仮 定して $M^{\prime}$ を平均することで集合組織のない多結晶に対す る $\bar{M}^{\prime}$ を求めた。

\section{IV. 結晶学的データ}

計算は代表的な形状記憶合金であり，そのマルテンサイ トの結晶学的なデータが報告されている CuZnAl, CuAlNi， TiNi の各合金について行なった。 CuZnAl 合金について

\begin{tabular}{|c|c|c|c|c|c|c|c|c|c|}
\hline Alloy & $\begin{array}{l}\text { Marten- } \\
\text { site }\end{array}$ & \multicolumn{3}{|c|}{$\begin{array}{l}\text { Habit Plane Normal } \\
\qquad\left\{h_{\mathrm{i}}\right\}\end{array}$} & \multicolumn{3}{|c|}{$\begin{array}{l}\text { Shear Direction } \\
<d_{\mathrm{i}}>\end{array}$} & $\eta$ & $\begin{array}{c}\text { Volume } \\
\text { Change } \\
\Omega\end{array}$ \\
\hline $\begin{array}{l}\text { CuZnAl } \\
\text { CuAlNi } \\
\text { CuAlNi } \\
\text { TiNi }\end{array}$ & $\begin{array}{l}\beta_{1}^{\prime} \\
\gamma_{1}^{\prime} \\
\beta_{1}^{\prime} \\
\beta_{1}^{\prime}\end{array}$ & $\begin{array}{l}0.1999 \\
0.2571 \\
0.1549 \\
0.0009\end{array}$ & $\begin{array}{r}-0.6804 \\
-0.6505 \\
-0.6830 \\
0.5811\end{array}$ & $\begin{array}{l}0.7050 \\
0.7147 \\
0.7138 \\
0.8138\end{array}$ & $\begin{array}{r}0.1817 \\
0.1754 \\
0.1421 \\
-0.8590\end{array}$ & $\begin{array}{l}0.7457 \\
0.7813 \\
0.7421 \\
0.3982\end{array}$ & $\begin{array}{r}0.6411 \\
0.5990 \\
0.6551 \\
-0.3219\end{array}$ & $\begin{array}{l}0.1866 \\
0.0955 \\
0.1687 \\
0.1088\end{array}$ & $\begin{array}{l}-0.00356 \\
-0.00341 \\
-0.00290 \\
-0.00340\end{array}$ \\
\hline
\end{tabular}
は, $\mathrm{DO}_{3}$ 規則相である母相から $18 \mathrm{R}$ の $\beta_{1}^{\prime}$-マルテンサイト への変態に対する Saburi とWayman ${ }^{(4)}$ の現象論による解 析を参考にして Chakravorty と Wayman(5)の報告した格 子常数を用いて WLR 理論 ${ }^{(6)}$ によって晶癖面法線 $h_{\mathrm{i}}$, 変位 ベクトル $d_{\mathrm{i}}$ ，その大きさクを求めた。 $\mathrm{CuAlNi}$ では $\mathrm{DO}_{3}$ の 母相から， $M_{\mathrm{S}}$ 温度近くでは $2 \mathrm{H}$ の $\gamma_{1}^{\prime}$ マルテンサイトが, より高温では $18 \mathrm{R}$ の $\beta_{1}^{\prime}$ マルテンサイトが生じることが 報告されている(7). そのらち ${ }^{\prime}$ については Saburi と Wayman ${ }^{(4)}$ による Otsuka とShimizu の格子常数 ${ }^{(8)}$ 用 いた現象論による解析結果をそのまま用いた。すなわち報 告されている $h_{\mathbf{i}}$ と変形マトリックスから $d_{\mathbf{i}}$ とをを逆算し た。 $\beta_{1}^{\prime}$ につては Otsuka ら (9)の得た格子常数を用い，

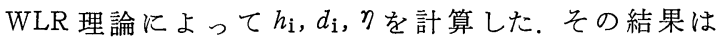
Otsuka ら ${ }^{(10)}$ が既に行なっている結果ともちろん一致し

Table 1 The Phenomenological data of martensites. See text for reference. 
た，TiNi については結晶学的データが必ずしも明らかで ないが, ここでは Knowles と Smith(11)によって行なわれ た B2 の母相から B19 の単斜晶マルテンサイトへの変態に ついての $(111)_{\beta_{1}^{\prime}}$ に添う Type I 双晶を格子不変変形とし た解析を再現した結果を用いた。それらのデータをTable 1 にまとめて示す。これらから式 (I - 12) によって求まる 変態ひずみの体積変化成分 $\Omega$ もあわせて示した。

\section{V. 計 算 結 果}

Fig.1 (a)から Fig.1 (d) に一軸引張について計算で得ら れた $M^{\prime}$ をステレオ三角形内の等高線で示す。図中の細線 は降伏曲面の同じ角点が動く方位領域を区切ったもので， その領域内では同じバリアントの組合せで変形が抢こる. このバリアントの組合せも計算から知れる。これらの同時 に発生, 成長するバリアント間の界面の性質や切りちがっ たときに起こる反応など，言い換えれば異なるバリアント

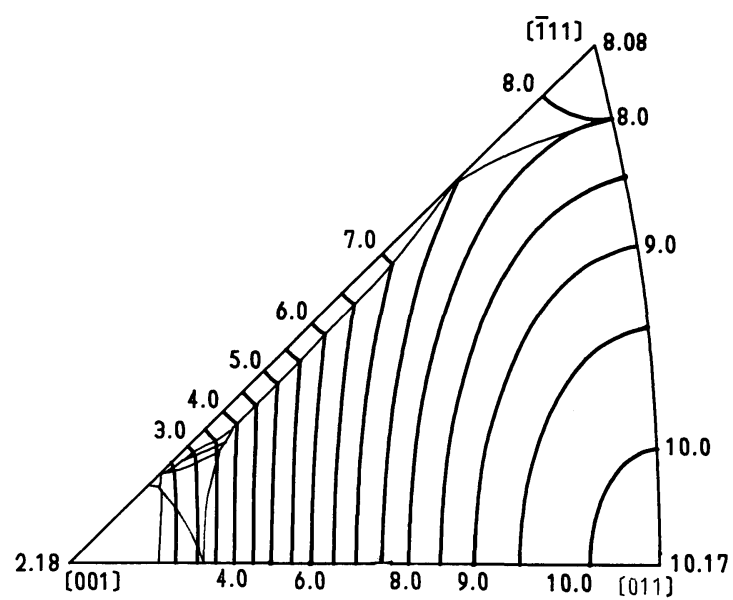

(a)

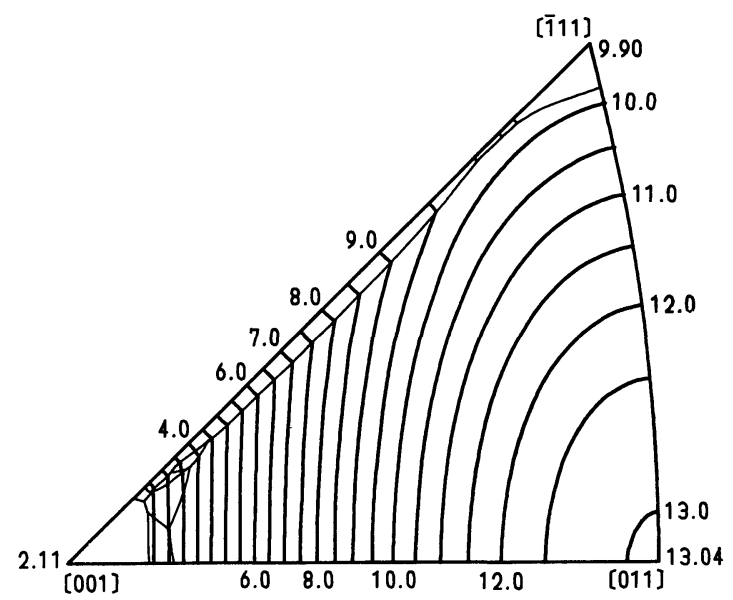

(c)
の相互作用が機械的性質に影響を及ぼすことも考兄られ る。しかしそのような詳細な検討は現在まだ無理と思われ るので，そのバリアントの組合せは本報告では割愛する。

Fig.1 から分かるように合金の違い，マルテンサイトの 違いにもかかわらず, CuZnAl と CuAlNi の両 $\mathrm{Cu}$ 合金の $M^{\prime}$ の方位依存性はバリアントの幾何学的配置の類似性を 反映して互いによく似ている。すなわらく $110>$ 方位が最 大の $M^{\prime}$ を示し，〈111>方位はそれよりやや小さい.さ らに $\langle 100\rangle$ 方位へ向かって $M^{\prime}$ は減少して, $<100>$ の 近くで最小值を示す。一方, TiNi 合金の $M^{\prime}$ は, $\langle 100\rangle$ 方位が最も大きく，〈110>方位，さらに< $<111>$ 方位へ 向かって小さくなっている。

$M^{\prime}$ の最大值, 最小値, それに平均值 $\bar{M}^{\prime}$ をTable 2 に 示した． $M^{\prime}$ の最小值は合金によってあまり違わず， 2 程 度の值となっている。これは，〈100>や〈111>のよう に対称性のよい方位では Taylor 因子は Schmid 因子の逆

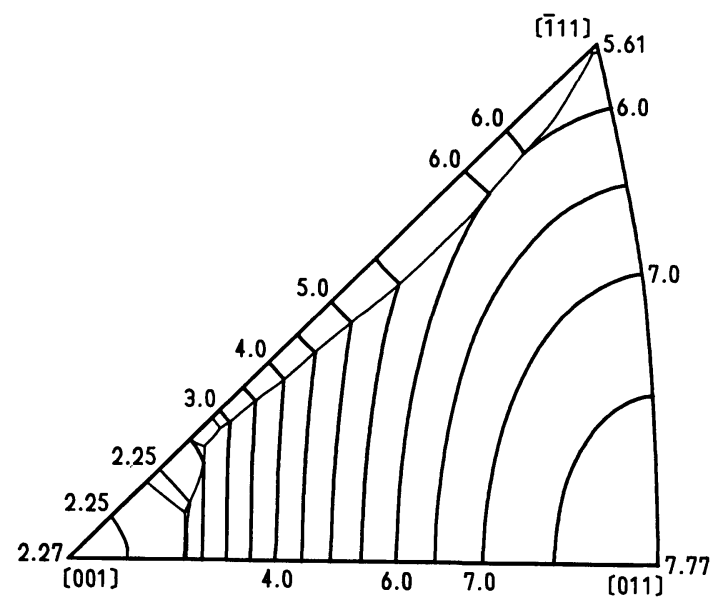

(b)

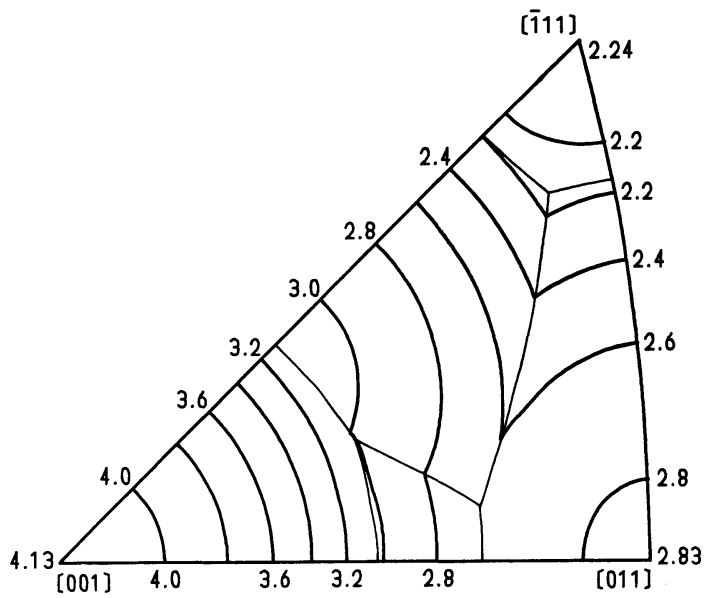

(d)

Fig.1 The "modified" Taylor factor, $M^{\prime}$, for tensile deformation by SIM, as a function of the orientation of the tensile axis.
(a) $\mathrm{CuZnAl}, \beta_{1}^{\prime}$ martensite.
(b) CuAlNi, $\gamma_{1}^{\prime}$ martensite.
(c) CuAlNi, $\beta_{1}^{\prime}$ martensite.
(d) TiNi. 
Table 2 Particular values and averages of $M^{\prime}$, also including the averaged inverse-Schmid factors.

\begin{tabular}{l|c|r|c|c|r|c}
\hline \hline Alloy & $\begin{array}{l}\text { Marten- } \\
\text { site }\end{array}$ & $M_{\max }^{\prime}$ & $M_{\min }^{\prime}$ & $\bar{M}^{\prime}$ & $\bar{M}$ & $\overline{1 / m}$ \\
\hline CuZnAl & $\beta_{1}^{\prime}$ & 10.17 & 2.11 & 7.46 & 7.84 & 3.01 \\
CuAlNi & $r_{1}^{\prime}$ & 7.77 & 2.17 & 5.74 & 6.16 & 2.45 \\
CuAlNi & $\beta_{1}^{\prime}$ & 13.04 & 2.06 & 9.56 & 10.11 & 2.74 \\
TiNi & $\beta_{1}^{\prime}$ & 4.13 & 2.15 & 2.91 & 3.00 & 2.40 \\
\hline
\end{tabular}

数に等しいため, Schmid 因子の最大值, 約 0.5 がそれら の極の近くにあれば Taylor 因子はその付近で最小值，約 2 をとるためである。これに対して， $M^{\prime}$ の最大值は合金 あるいはマルテンサイトの種類によって大きく異なる。特 に TiNi 合金の $M^{\prime}$ の最大值 4.13 に比べて $\mathrm{Cu}$ 合金では最 も小さいCuAlNi の $\gamma_{1}^{\prime}$ マルテンサイトが 7.77, 最も大き い同合金の $\beta_{1}^{\prime}$ マルテンサイトで 13.04 と大きい值である ことが注目される。このような $\mathrm{Cu}$ 合金と TiNi 合金の違 いには Fig.1 に見られる働く角点の方位依存性にも現れて

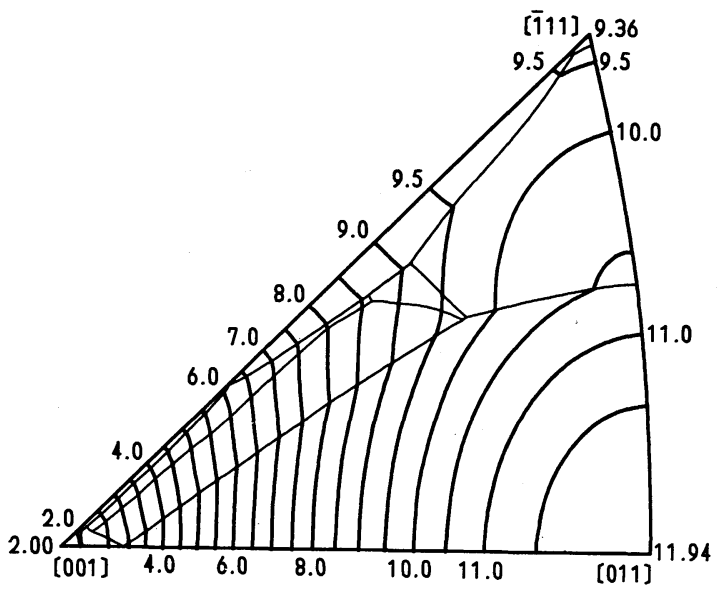

(a)

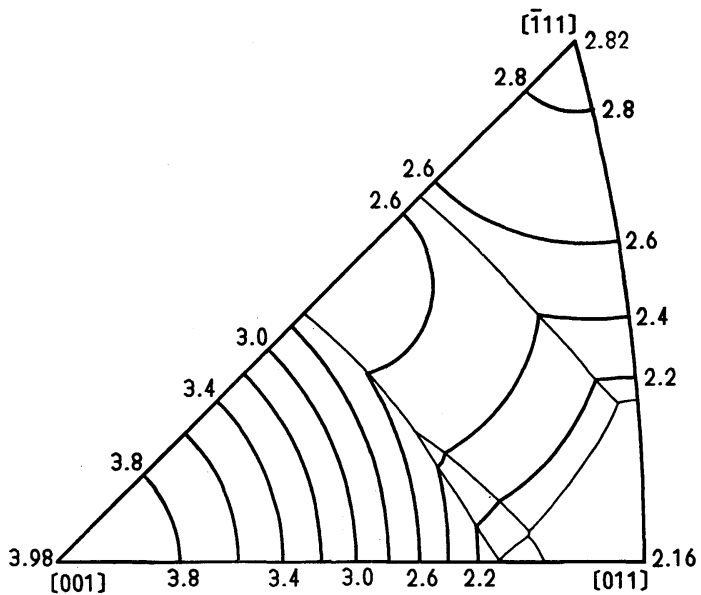

(b)

Fig.2 The "modified" Taylor factor for compressive deformation by SIM, as a function of the orientation of the compressive axis.

(a) CuZnAl, $\beta_{1}^{\prime}$ martensite. (b) TiNi.
いる、すなわち， $\mathrm{Cu}$ 合金では多くの種類の角点が現れて いるにもかかわらず〈110〉を中心にした広い方位領域が 一つの角点の活動でまかなわれている：これに対し，TiNi 合金では，少数の角点がステレオ三角形の中で均等な領域 を占めている。

上記の各合金, 各マルテンサイトについて,一軸圧縮の 場合の計算も行なった，その結果のうち CuZnAl と TiNi 合金の場合を Fig.2(a) と Fig.2(b)に示した. 式(11)の定 義から $M^{\prime}$ はこのときすべて負の值となるが，さしつかえ ないかぎり暗黙のうちにその絶対值を示すことにする．各 バリアントが一方向へのせん断しか生み出さない事の結果 として，発生するバリアントの組合せは引張の時と全く異 なっている. 颃もな数值は $\mathrm{CuAlNi}$ 合金の結果も含めて

Table 3 に示した. $M^{\prime}$ の方位依存性の傾向は引張の場合 とよく似ていて，例えばく100>方位の $M^{\prime}$ が CuZnA1で は最小, TiNi では最大となっている。. $M^{\prime}$ の最大值も引張 の場合と同じように Cu 合金に比べて TiNi 合金では小さ い.これと $M^{\prime}$ の最小值が合金によらず約 2.0 であること の結果として, $\bar{M}^{\prime}$ むu 合金では大きく, TiNi では小さ い.

Table 3 Particular values and averages of $M^{\prime}$ for compression.

\begin{tabular}{l|c|r|r|r|r|r}
\hline \hline Alloy & $\begin{array}{l}\text { Marten- } \\
\text { site }\end{array}$ & $M_{\max }^{\prime}$ & $M_{\min }^{\prime}$ & $\bar{M}^{\prime}$ & $\bar{M}$ & $\overline{1 / m}$ \\
\hline CuZnAl & $\beta_{1}^{\prime}$ & 11.94 & 1.99 & 9.10 & 8.60 & 3.05 \\
CuAlNi & $r_{1}^{\prime}$ & 8.88 & 1.99 & 6.94 & 6.41 & 2.94 \\
CuAlNi & $\beta_{1}^{\prime}$ & 14.80 & 1.99 & 11.20 & 10.53 & 3.59 \\
TiNi & $\beta_{1}^{\prime}$ & 3.98 & 2.06 & 2.76 & 2.68 & 2.22 \\
\hline
\end{tabular}

\section{VI. 考察}

上記のように計算された $M^{\prime}$ から $\bar{M}$ は式 (I -37), 改め て書けば

$$
\bar{M}=\bar{M}^{\prime}\left(1+\frac{\bar{M}^{\prime} \Omega}{3 \eta}\right)^{-1}
$$

と与えられる.引張と圧縮に和ける $\bar{M}$ をTable 2 と Table 3 にそれぞれ示した. これらの合金では $\Omega<0$ であ り，また式(11)の $M^{\prime}$ の定義による $M^{\prime}$ の符号によって式 (12)のかっこ内の第 2 項は引張では $\bar{M}^{\prime}$ に比べて $\bar{M}$ を大 きくするように，圧縮ではその逆に㗢く，その大ささは最 も影響の小さい TiNi で約 $3 \%$, 最も大きいCuAlNi の $\gamma_{1}^{\prime}$ について 7〜8\%である.

この $\bar{M} を$ 用いて多結晶の降伏応力 $\bar{\sigma}_{1}$ とバリアント成 長の臨界塑性仕事 $W^{*}$ は次のよらに結び付けられる。すな わち式( I - 36)より

$$
\bar{\sigma}_{1}=\bar{M} W^{*} / \eta
$$

また，ひずみの回復応力 $\bar{\sigma}_{1}^{\mathrm{R}}$ は上で述べたように式 (5) で与えられる。 $W^{*}$ は式 $(I-14),(I-15)$ の内容を持つもの なので, $\bar{\sigma}_{1}$ の温度依存性は 


$$
\delta \bar{\sigma}_{1} / \delta T=\frac{\bar{M}}{\eta} \cdot \delta W^{*} / \delta T=\bar{M} \cdot \Delta S / \eta
$$

と与えられる。もしバリアントの成長, 収縮にともならエ ネルギーの散逸 $\Delta G_{\mathrm{f}}$ が温度によらなければ， $\bar{\sigma}_{1}^{\mathrm{R}}$ も同じ温 度依存性を示す。

すべり変形する多結晶の場合からの類推では，これらの 関係は定量的にかなり正確であるうと予測される(1)。しか し，SIM についてはここで考慮した事柄以外に多段変態(7) や応力下で安定なバリアントの粒方位依存性 ${ }^{(12)}$, 複数の マルテンサイトの共存 ${ }^{(13)}$ などの複雑な挙動が報告されて いる。また，すべり変形がいか溧どの割合で混在し，どの よらな役割を果たすのかも必ずしも明らかではない，その 意味で本研究の計算結果はひとつの理想的な挙動に対応す るもので，これらと実駼結果を比較検討することで上式の 定量的な正確さが評価され，また多結晶合金の応力誘起変 態の理解が深められるものと期待される.

そのような検討は，例党ば式 (13) と式(14) とよって単結 晶の実験から求めた $W^{*} / \eta$ やその温度依存性と，それと 同じ合金の多結晶の降伏応力やその温度依存性を比較する ことで行ならことができるが，現在のところとれに必要な 系統的な実験結果は見当らない，そこで以下では本研究の 計算結果の示唆することがらについて定性的に述べる.

\section{1. 降伏応力, 回復応力および回復ひずみ}

Table 2 と Table 3 には均一な粒方位分布に対する Schmid 因子の逆数の平均値 $\overline{1 / m}$ も示してある。これを $\bar{M}$ と比較すると TiNi 合金ではあまり違いはなく，その 比, $\bar{M} /(\overline{1 / m})$ は引張, 圧縮ともに 1.2 程度の值である。 $\mathrm{Cu}$ 合金では違いが大きく，その比の小さいCuAlNi 合金 の $\gamma_{1}^{\prime}$ マルテンサイトでも 2.3 , 最も大きい同合金の $\beta_{1}^{\prime}$ マ ルテンサイトでは 3.5 に達している。これから $\mathrm{Cu}$ 合金に 抒いては, 単結晶の降伏応力やその温度依存性に比べて多 結晶の降伏応力, それに回復応力や応力ヒステリシスは結 晶粒相互の拘束のために Schmid 因子の平均值を用いた予 測よりるかなり大きい值になると期待される。

Schmid 因子にもとづいてすでに指摘されているよう

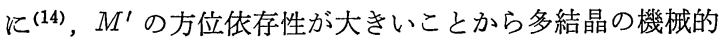
性質に対する集合組織の影響が大きいことが期待される. ここで, 各方位の結晶粒の, 多結晶の平均的性質への寄与 のしかたが Taylor 因子による評価とSchmid 因子による それでは必ずしも一致しないことは注意を要する。例光 ば, CuZnAl とCuAlNi の両合金について見ると， $M^{\prime}$ は ＜111>方位と<110>方位ではいずれるかなり大きい值だ が前者のほうがやや小さくなっている。一方，1/mは

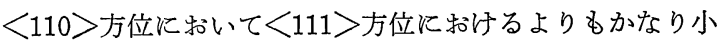
さい(14).

およその見積もりのために体積変化の寄与を無視すれ ば，各結晶粒に打ける軸ひずみ $\varepsilon_{1}^{\prime}$ とマルテンサイトの体 積比 $v$ の関係は式(11)で与兄られる。 $v=1$ として得られ
るSIM によって可能な最大のひずみはしたがって，

$$
\varepsilon_{1}^{\prime \max }=\eta / M^{\prime}
$$

となる， $M^{\prime}$ が最大の方位に対するこの $\varepsilon_{\text {max }}^{\prime}$ をTables 1, 2 打よび 3 亿与党た数值から計算すると，引張の場合， CuZnAl では $1.8 \%$, CuAlNi の $\gamma_{1}^{\prime}$ と腅についてそれぞれ 1.2 と $1.3 \%$, TiNi そついて $2.6 \%$ となる。これらの值は 単一の対応バリアントについて計算されたいわば単結晶の 一軸変形飞対する値 ${ }^{(14)}$ よりいくらか小さい，乙かし，降 伏応力の予測に拈ける $\bar{M}$ と $\overline{1 / m}$ の違いの上らな大きな違 いではないのは，単結晶に打いても不利な方位では最大可 逆ひずみが小さいためである。ただし，例党ば $\mathrm{Cu}$ 合金で は，<110>方位はSchmid 因子ではそれはど不利な方位 ではないが， $M^{\prime}$ にるる評価では最も不利な方位になる。 集合組織の評価にあたってはこのような粒間の相互拘束の 効果に留意する必要がある。

回復ひずみという観点からは，このように $M^{\prime}$ の大きい 方位の結晶粒は好ましくない，一方，そのような方位の結 晶粒が多くその 結果 $\bar{M}$ が大きいと，式( 5 ) とよって回復 応力やその温度依存性が大きくなるので，実用上好ましい とも考觉られる。これから，いかなる粒方位分布が適切で あるかは各応用例について具体的に検討されるべきものと 考觉らる。

\section{2. 破壊強度}

材料の破壊は平均的な応力よりも局所的な応力に支配さ れるところが大きいと考兄られる。これから $M^{\prime}$ の方位依 存性すなわち塑性異方性が大きいことは材料の延性をとこ なう要因となると考兄られる。

これはひとつには粒ごとの軸応力 $\sigma_{1}$ が $M^{\prime}$ にほぼ比例 し，乙たがって $M^{\prime}$ の大きな粒には平均応力 $\bar{\sigma}_{1}$ 以上の応 力が働くという直接的な効果によって起こるが，さらによ り微視的な次のような過程が考光られる。

多結晶に怙いては，バリアントプレートの成長は粒界や 交差する他のバリアントによって止められる，そこでは， 大きな応力集中が発生すると考光られる(15)(16)，その応力 集中は局所的な塑性変形によって緩和されて，いわば微視 的なひずみの整合性が保たれる，そのために必要な塑性変 形は粒方位や粒界方位，バリアントの種類などによって個 々の場合ごとに異なっているであろう. Taylor 因子は結晶 飞任意の塑性ひずみを与えるために必要な応力の尺度であ るので, 結局このような応力集中の大きさはそれを緩和す るに必要な塑性ひずみに対する Taylor 因子の大きさに依 存することになる。本研究で計算したのは一軸変形に対す る Taylor 因子だけではあるが，これからでも各合金の SIM 飞よる変形の塑性 異方性の大きさは定性的に推察で きる。すなわち， TiNi 合金で $M^{\prime}$ の方位依存性がすべり 変形する fcc, bcc 結晶と同程度であって塑性異方性が小さ く，局所的な応力集中が SIM 飞よって比較的容易飞緩和さ れると思われる。一方，Cu 合金では大きな塑性異方性の 
ために時としてそれが著しく困難であると推測される.

これらの応力のほかにＩに拈いて SIM で変形する多結 晶の結晶粒には式 (I - 33) で表される体積変化の粒ごとの 不均一に起因する静水圧応力 $\Delta \sigma_{\mathrm{m}}$ が加わると見積もられ た. 改めて書けば

$$
\Delta \sigma_{\mathrm{m}}=-G^{\prime} \Omega \bar{\varepsilon}_{1}^{\prime} \Delta M^{\prime} / \eta
$$

この応力 $\Delta \sigma_{\mathrm{m}}$ を引張ひずみ のが Table 4 である、 $\Delta \sigma_{\mathrm{m}}>0$ ，すなわち引張の場合が破 壊に対して問題となり，これらの合金では $\Omega<0$ であるの で $\Delta M^{\prime}>0$ の最大值について計算した。㹺およその見積も りのため剛性率の值は $\mathrm{Cu}$ 合金には純 $\mathrm{Cu}$ の一般的な值, $46000 \mathrm{MPa}$ を用いた。 ポアソン比は $1 / 3$ とした。 TiNi につ いては, Mercier と Török(17)の NiTiCu のヤング率, 約 $100 \mathrm{GPa}$ から等方弾性体を仮定し，ポアソン比を1/3として 求めた剛性率 $37500 \mathrm{MPa}$ を用いた。得られた值は TiNi 合 金では $12 \mathrm{MPa}$ 程度, 最も大きい $\mathrm{CuAlNi}$ の $\gamma_{1}^{\prime}$ マルテン サイトで約 $30 \mathrm{MPa}$ であってあまり大きくない. しかしこ の応力は平均化されたマトリックスを基準に体積変化の差 を見積もっているので局所的にはもっと大きい值となる可 能性も考元られる。この意味からも $M^{\prime}$ の方位依存性が大 きいことは好ましくないと言える。

Table 4 Stresses caused by the grain orientation dependence of volume change due to the tensile strain of 0.01 . See text for detail.

\begin{tabular}{c|c|c|c|c}
\hline \hline Alloy & $\begin{array}{c}\text { Marten- } \\
\text { site }\end{array}$ & $\begin{array}{c}\Delta \sigma_{\mathrm{m}} \\
(\mathrm{MPa})\end{array}$ & $\overline{\Delta M^{\prime 2}}$ & $\begin{array}{c}3 h / 2 \\
(\mathrm{MPa})\end{array}$ \\
\hline CuZnAl & $\beta_{1}^{\prime}$ & 21.2 & 4.46 & 0.66 \\
CuAlNi & $r^{\prime}$ & 29.9 & 2.36 & 1.23 \\
CuAlNi & $\beta_{1}^{\prime}$ & 24.6 & 7.41 & 0.90 \\
TiNi & $\beta_{1}^{\prime}$ & 12.6 & 0.24 & 0.08 \\
\hline
\end{tabular}

以上，個々の結晶粒あるいはより局所的に平均応力とは 異なる応力が作用する原因として 3 つの理由を考察した。 それらのいずれに対しても Taylor 因子 $M^{\prime}$ ，あるいはそ の方位依存性が大きいことは好ましくなく，その材料の延 性の低下に結び付く可能性がある，このような推測に対し て，一般に知られている $\mathrm{TiNi}$ 合金と $\mathrm{Cu}$ 基合金の延性の 違いは正しく対応している。したがって, 粒界の強度やす ベり変形の容易さ, 弾性異方性の程度などの要因に加えて ここで述べてきたような塑性異方性もこれらの合金の破壊 挙動に重要な影響を及ぼしているものと考えられる。

\section{3. 応力ーひずみ曲線}

Iにおいて結晶粒ごとの体積変化の不均一に起因する静 水圧内部応力が平均として線形の加工硬化を与えることを 述べた，その大きさは式（I-34）で与えられる．改めて書 けば

$$
\frac{3}{2} h=G^{\prime}(\Omega / \eta)^{2} \overline{\Delta M^{\prime 2}} \bar{\varepsilon}_{1}^{\prime}
$$

本研究で得られた引張の $M^{\prime}$ の方位依存性から，均一な粒 方位分布に対して $\overline{\Delta M^{\prime 2}}$ を求め，この加工硬化の大きさを
見積もった結果をTable 4 に示す． $\bar{\varepsilon}_{1}^{\prime}=0.01$ に护硬 化量は最も大きいCuAlNi の $\gamma_{1}^{\prime}$ マルテンサイトの場合で も $1 \mathrm{MPa}$ のオーダーであって, 実際的には全く無視して よい大きさである。したがって，この項の寄与を無視した (I -35)，(I-36) それに（I -37)の各式や上で述べた式 (5) はこれらの合金については十分によい近似であることがわ かる。

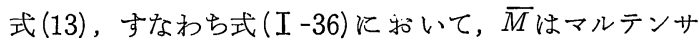
イトバリアントの幾何学的配置と粒方位分布によって定ま る幾何学的因子であり,ひずみによらず一定である.すると 実験的に観察される加工硬化挙動はもっぱらひずみの増加 にともなら $W *$ 増加に帰されることになる。単結晶の SIM では 1 つないし少数の母相/マルテンサイト界面の移 動によるマルテンサイト体積比の増加によってひずみの増 加がおこるので, 本質的に $W *$ *ひずみによる変化は期待 されない，実際， $\mathrm{Cu}$ 合金について報告されている単結晶 の応力 -ひずみ曲線はほとんど加工硬化を示さない(10)(18) (19)。すると本解析の範囲では多結晶においても加工硬化 のない応力ーひずみ曲線が予測される、実際，TiNi 合金 ではそのような応力 -ひずみ曲線が観察される(20)-(22). これに対して $\mathrm{Cu}$ 基合金多結晶の加工硬化率は一般にかな り大きく，また結晶粒径依存性を示すことも報告されてい る(23).これは Taylor モデルからは予想されないことな ので，モデルで考慮されていないより微視的な要因が働い ているものと考えられる。

例えば Christian ${ }^{(24)}$ は,多結晶では成長するバリアントと 粒界，あるいは異なるバリアントの間の相互作用などによ ってひずみの増加，すなわちマルテンサイトの体積比の増 加とともに新たなバリアントの発生と成長に，より大きな 駆動力が必要になると述べている，このような過程は前節 で述べた微視的なひずみの整合性の条件と同じものである ので, $M^{\prime}$ の方位依存性の影響を同じように受けると予想 される。そこで TiNi 合金と $\mathrm{Cu}$ 基合金を比較すると $M^{\prime}$ の方位依存性の大きさと加工硬化の大きさが定性的にでは あるがよく対応していることがわかる。

\section{VII. ま と め}

本研究ではまず，基本的に Taylor モデルにもとづく前 報Iの考察の簡単な拡張によって SIM により変形した多 結晶のひずみの回復応力をも取り扱えることを示した。さ らに, 一軸変形について計算で求めた各合金, 各マルテン サイトの「修正」Taylor 因子 $M^{\prime}$ の值とその方位依存性 を報告し，それにもとついて，それらと多結晶の降伏応 力, 回復応力, 擬弾性ヒステリシス, 回復可能ひずみ量, これらに対する集合組織の影響, 延性, 加工硬化などの関 係を定性的に検討した。このような関係が確認されれば， 例えばある合金が新しい形状記憶合金の候補に挙げられた ときそその合金のマルテンサイトの結晶学的知見だけから 
現象論と Taylor モデルを用いた本研究の方法によってそ の合金の多結晶状態での機械的性質がある程度予測できる ことになる。

上で述べたように実際の形状記憶合金では本研究で考慮 した以外に多段マルテンサイト変態や発生するマルテンサ イトの方位依存性といった複雑な過程が起こる可能性があ る。もし必要なら，そのような挙動をも解析に取り込む工 夫をするとともに，前報I と本研究で行なったよらな単純 化された取扱いが多結晶の機械的性質を予測する上でどの 程度正確であるかを実験的に検証することが今後の課題で あり，そのための実験結果の充実が望まれる.

終りに本研究についてご助言をいただいた本間敏夫教 授, 渡辺 真教授, 守護嘉朗博士に謝意を表する。また東 北大学学生, 津嶋孝博 (現在 : シチズン時計 (株)), 佐藤 佳裕 (現在：日産自動車 (株))の諸君の協力に感謝する。本 研究の計算は東北大学大型計算機センターで行なったこと を付記する。

\section{文献}

（1）小野 陽, 佐藤 敦：日本金属学会誌, $50(1986)$, 777 .

(2) J.F.W.Bishop and R.Hill : Phil. Mag., 42 (1951), 414,1298

（3）関根泰次：数理計画法 I，岩波基礎工学 5 , 岩波書 店, (1968).

(4) T.Saburi and C.M.Wayman : Acta Metall., 27 (1979), 979.

(5) S.Chakravorty and C.M.Wayman : Acta Metall., 25 (1977) , 989
(6) M.S.Wechseler, D.S.Lieberman and T.A.Read: Trans. AIME, 197 (1953), 1503.

(7) K.Otsuka and K.Shimizu:Proc. Int. Conf.SolidSolid Phase Transformations, H.I.Aaronson et al. (eds.), AIME, (1981), 1267.

(8) K.Otsuka and K.Shimizu:Trans.JIM, 15(1974), 103.

(9) K.Otsuka, T.Nakamura and K.Shimizu:Trans. JIM, 5 (1974) , 200

(10) K.Otsuka, C.M.Wayman, K.Nakai, H.Sakamoto and K.Shimizu : Acta Metall., 24 (1976), 207.

(11) K.M. Knowles and D.A.Smith : Acta Metall., 29 (1981), 101.

(12) H.Tas, L.Delaey and A.Deruyttere : Z.Metal1kde., 64 (1973) , 855, 862.

(13) A.Ritter, N.Y.C.Yang, D.P.Pope and C.Laird: Metall. Trans., 10A (1979), 667.

(14) T.Saburi and S. Nenno: Proc. Int. Conf. SolidSolid Phase Transformation, H.I.Aaronson et al. (eds.), AIME, (1981), 1455.

(15) A.N.Stroh : Proc. Roy. Soc. Lond., A223 (1954), 404.

(16) H.Sakamoto, Y.Kijima and K.Shimizu : Trans. JIM, 23 (1982) , 585.

(17) O.Mercier and E.Török : J.de Phys., 43 (1982), C4-267.

(18) K.Otsuka, H.Sakamoto and K.Shimizu : Acta Metall., 27 (1979) , 585.

(19) T.Saburi, Y.Inada, S.Nenno and N.Hori : J.de Phys., 43 (1982) , C4-633.

(20) S.Miyazaki, K.Otsuka and Y.Shimizu : Scr. Metall., 15(1981), 287.

(21) T.Saburi, T.Tatsumi and S.Nenno : J.de Phys., 43 (1982), C4-261.

(22) T.Saburi, M. Yoshida and S.Nenno : Scr.Metall., 18 (1984), 363.

(23) G.N.Sure and L.C.Brown : Metall. Trans., 15A (1984), 1613.

(24) J.W.Christian : Metall. Trans., 13A (1982), 509. 